\title{
Creating sustainable performance in the fourth industrial revolution era: The effect of employee's work well-being on job performance
}

\author{
Rizal Nangoy ${ }^{a^{*},}$ Tirta Nugraha Mursitama ${ }^{b}$, Nugroho Juli Setiadia and Yosef Dedy Pradipto ${ }^{c}$
}

\author{
${ }^{a}$ Management Department, BINUS Business School, Doctor of Research in Management, Bina Nusantara University, Jakarta, Indonesia \\ ${ }^{b}$ International Relations Department, Faculty of Humanities, Bina Nusantara University, Jakarta, Indonesia \\ ${ }^{c}$ Psychology Department, Faculty of Humanities, Bina Nusantara University, Jakarta, Indonesia

\section{H R O N I C L E}

\section{A B S T R A C T}

Article history:

Received: October 152019

Received in revised format: Octo-

ber 282019

Accepted: November 3, 2019

Available online:

November 5, 2019

Keywords:

Industrial Revolution

Job Performance

Millennial

Sustainable Performance

Work Well-being
In the beginning of the fourth industrial revolution, competition in acquiring and retaining best talents in concert with talents' unfamiliarity of what they will face and obtain in the course of working at a company are two major problems. It is essential for a company to make its employees satisfied and pleased with their jobs. These very satisfaction and pleasure are hoped to serve as a key for motivating employees to perform and contribute their best for the company. Numerous research studies have proven the positive effect of work well-being on job performance, but the findings came with inconsistencies and controversies. This fact has caused reluctance in a good many companies to invest in their employees' work well-being. A survey of 509 millennial employees in the Indonesian startup digital industry was conducted in this research. The results show that employee's work well-being had a significant, positive effect on job performance. Theoretically, this research has contributed in responding to inconsistencies in literature. It is hoped that this research will also offer practical contribution to individual employees as well as human resources department and increase company executives' confidence in making organization-related strategic decisions to attain sustainable performance. Finally, we propose a number of intervention suggestions for performance improvement through work well-being.

C) 2020 by the authors; licensee Growing Science, Canada

\section{Introduction}

In the beginning of the fourth industrial revolution, competition in acquiring and retaining best talents in concert with talents' unfamiliarity of what they will face and obtain in the course of working at a company are two major problems (Amelia, 2018; Schwab \& Samans, 2016), reflecting changes in employer-employee relationship (Gratton, 2011). With regard to talent and skill, the world now is facing shortages (BCG, 2012; Manpower, 2014). This brings companies' attention to the necessity of re-identifying the manners in which human resources' strategic roles are seen. Many high-profile companies even assert that people are the key for company's success. But why is it important for them to invest in people? Employees are not necessarily motivated by various employee development and employee engagement programs as well as benefit and advancement opportunities to contribute to a company (Colquitt et al., 2017). It becomes essential, then, for companies to make their employees satisfied and pleased with their jobs. These very satisfaction and pleasure are hoped to serve as a key for motivating employees to perform and contribute their best for them (Gratton, 2011; Schotanus-Dijkstra et al., 2016). Numerous research studies have proven the positive effect of work well-being on job performance (Etrugul, 2013; Moniz \& de Jong, 2014; Tenney et al., 2016; Warr \& Nielson, 2018), but some came with a multitude of inconsistencies and controversies, for example, Kagan (2016), Murphy et al. (2015), as well as Oswald et al. (2015). This fact has caused reluctance in a good many companies to invest in their employees' work well-being. In view of this, this research was conducted with the purpose of quantitatively examining the effect of employee's work well-being on job performance. As explained by Kim and Ploychart (2014), job performance is the basis for the economy as a whole. It establishes organizational performance and even contributes to the economic growth of a country.

* Corresponding author. Tel.: +62 811801886

E-mail address: rizalmmgd@gmail.com (R. Nangoy) 
The evidence of employee's well-being's influence on job performance will be of a considerable use to individual employees, human resources department management, and, especially, company executives for strategic decision-making. Organizational management strategies that apply positive approaches through well-being improvement involve the whole organization and considerable human resources and are long-term-oriented. This research was carried out in the hope that to increase strategic decision makers' confidence in making investment in human resources, especially in employee's work well-being. In this manner, the strategies devised by the company are expected to have a positive effect on its individual employees, organization, and the public in general, with no party feeling threatened and, because of that, protesting against these strategies, and hence, the company will be enabled to grow and sustain its existence (Warr \& Nielsen, 2018).

\section{Literature Review}

\subsection{Work Well-being}

Scientific studies on well-being (often equated with happiness) are built on two primary philosophical bases: hedonic perspective or happiness and eudaimonic perspective or self-actualization (Woyciekoski et al., 2012). Hedonic perspective (subjective well-being, SWB) is related to experiences of pleasure and displeasure (Giacomoni, 2004), highlighting an individual's subjective aspect or personal evaluation in their life (Diener \& Chan, 2011; Diener et al., 2010). In this perspective, an ideal well-being condition is characterized by high levels of positive affect and life satisfaction and low levels of negative affect (Deci \& Ryan, 2008). Meanwhile, the eudaimonic perspective construes well-being as more than just happiness. This perspective puts an emphasis on psychological well-being and regards happiness as a vital part of well-being, but not as the only indicator, requiring the accompaniment of other self-fulfillment indicators (Albuquerque \& Trocolli, 2004; Ryff, 1989; 2013). In other words, well-being is not just a transient subjective state, but is inclusive of potential development and attempts to achieve a better life (Diener \& Chan, 2011; Keyes \& Simoes, 2012). Researchers have exerted a great deal of effort to develop instruments for well-being studies based on the abovementioned two perspectives. Among these instruments are the Satisfaction with Life Scale (Diener et al., 1985), the Positive and Negative Affect Schedule (Watson et al., 1988), the Scales of Psychological Well-Being (Ryff \& Keyes, 1995), the Questionnaire for Eudaimonic Well-Being (Waterman et al., 2010), and the Flourishing Scale (Diener et al., 2010; Seligman, 2011). The Flourishing Scale, an instrument for measuring well-being, comprises five aspects, namely positive emotions, engagement, relationship, meaning in life, and accomplishment or achievement. Seligman (2011) calls these aspects in short as PERMA. The Flourishing Scale later gains popularity among many researchers from different countries as an instrument for well-being after addressing the shortcomings found in earlier wellbeing measurement instruments (including Fonseca et al., 2015; Huppert \& So, 2013; Schtanus-Djikstra et al., 2016; Silva \& Caetano, 2013; Sumi, 2013). All of the research studies show high levels of reliability (Cronbach's alpha $>0.80$ ). This research measured employee's well-being construct by the Flourishing Scale which had previously been adjusted to the job context. This scale has been acknowledged to possess two major advantages over other well-being measurement instruments. First, this instrument is based on the integration of SWB and PWB (Sumi, 2013). Second, it is proven to have a fairly high level of internal consistency $(\alpha>0.80)$.

\subsection{Job Performance}

The job performance measured in this research referred to performance as behavior (Colquit et al., 2017). One form of this sort of performance is called construct job performance (Campbell \& Wiernik, 2015; Fay \& Sonnentag, 2010; Koopmans et al., 2013). This research measured job performance in four dimensions by means of self-report: task performance; contextual performance; adaptive performance; and innovative performance. This subjective way of measurement was selected as it had been proven better at predicting future behaviors than was traditionally the case when objective indicators were used (Reijonen \& Komppula, 2007; Wach et al., 2016). Behavior-based employee performance measurement development departed from Murphy's (1989) and Campbell's studies (1990), which explicate that individual employee performance is a latent construct whose measurement cannot be performed in a direct manner. Campbell and Wiernik (2015) later defined job performance as the behavior of an individual employee which has relevance with their organization's goal. Three key points in the definition are worth noting: (1) performance is defined as the behavior itself rather than the outcomes of the behavior; (2) performance encompasses only the behaviors that are relevant with organizational goals; and (3) performance is a multidimensional construct. Motowidlo et al. (1997) described performance construct in two dimensions, namely task performance and contextual performance. Task performance is defined as how an employee behaves to fulfil their job description, while contextual performance is defined as a behavior that supports organizational, social, and psychological environments and is consistent with the organization's goal. In response to recent environmental dynamics, Sinclair and Tucker (2006) as well as Haneberg (2011) added the dimension adaptive performance as a discrete domain in job performance measurement. This dimension focuses on interdependent development, uncertainties in a work system, and constant changes in a work setting. In later time, Shipton et al. (2016) as well as Spanuth and Wald (2017) developed a measurement of innovative or creative behavior as an added dimension that should be considered in performance measurement. This dimension is defined as the degree to which an employee generates, promotes, and maintains fresh ideas that may benefit their organization.

\section{Hypothesis development}

The broaden-and-build theory of positive emotion (Fredrickson, 2009) explains that happy individuals have positive emotions that stimulate their minds to broaden in responding to environmental stimuli. A number of studies have showed that happy employees tend to receive better evaluation from their supervisors and earn higher income than their peers (Koo \& Suh, 2013; 
Warr \& Nielson, 2018). Another study by Tenney et al. (2016) concluded that happy employees tend to be more competent than averager. It has also been concluded that happy employees have better productivity and performance (Oswald, Proto, and Sgroi, 2015; Bouckenooghe, Raja, and Butt, 2013). Kaufman and Sternberg (2010) described happy employees as more creative and innovative in completing their works, while Jiang and Tagard (2014) point out that happy employees are not resistant to innovations, work in team better, and support firm performance in general. Previously, De Neve and Oswald (2012) concluded that work well-being can predict an individual's job performance in the future. Based on the description above, the following hypothesis is proposed.

$\mathrm{H}_{1}$ : Work well-being has a positive effect on job performance.

\subsection{Research Method}

This research is a field study with a quantitative method and cross-sectional design. Data collection was performed by a questionnaire survey of respondents who voluntarily consented to participate in this study. The data were collected from respondents' self-report with maintenance of anonymity, and it was hoped that they would answer according to the real condition and avoid such biases as social desirability and consistency motives (Podsakoff et al., 2003). Measurement of work well-being and job performance was performed by questionnaires, each of which used 6-point Likert scale to avoid central tendency bias (DeVellis, 2017), starting from (1) "strongly disagree" to (6) "strongly agree". Convenience sampling was selected for this research. Despite its weakness in its generalization capability, this sampling technique was deemed appropriate for studies which involve psychological perceptions and individual self-reference in that the respondents would be willing to complete the questionnaires administered voluntarily (Podsakoff et al., 2003). We carried out a survey from April to June of 2019 on the employees of ten major companies (seven of which belonged to the unicorn category) in the startup digital industry in Indonesia. To test the hypothesis and the model's fitness with the data, this research used the structural equation modeling. Following Anderson and Gerbing (1988), the data analysis was conducted in two stages. First, the analysis was conducted on the measurement model using the confirmatory factor analysis (Doll et al., 1994). Second, the analysis was conducted using the structural model analysis. The item validity was determined using a minimum standardized factor loading of 0.50 (Wijanto, 2015). Meanwhile, the reliability was determined using composite reliability measure through the calculation of construct reliability (CR) and average variance extracted (AVE). The measurement would be declared reliable if the CR value was $>0.70$ and the AVE value was $>0.50$ (Wijanto, 2015). After the model was confirmed to be fit with the data using the goodness of fit test indicator $(\mathrm{GoFI})$, the hypothesis was tested by comparing the $\mathrm{t}$-value with the critical value $(\mathrm{t}>$ $1.96, \alpha>0.05)$ to conclude whether there was significant correlation.

\section{Results and Discussion}

This research involved 509 respondents, consisting of 312 males and 197 females, with average age of 27.52 years (SD 2.351). Most of the participants had a bachelor's degree $(89.20 \%)$. All control variables tested in this study (gender, educational level, and marital status) did not show a significant effect; thus, the control variable can be excluded from the research model (Spanuth \& Wald, 2017). Next, structural equation modeling analysis was performed on the measurement model by using confirmatory factor analysis method, in which work well-being variable was analyzed in the 1st order while the variable of job performance was analyzed in the 2 nd order. The results are presented in Table 1 below:

Table 1

Measurement Model using Confirmatory Factor Analysis

\begin{tabular}{|c|c|c|c|c|c|}
\hline \multicolumn{2}{|c|}{ Construct level } & Measurement indicator & Coding & Loading factor $(\lambda)$ & $\frac{\text { Sig. }}{\text { (t-value) }}$ \\
\hline $2^{\text {nd }}-$ Order & $1^{\text {st }}$-Order & & & & \\
\hline \multirow{22}{*}{$\begin{array}{l}\text { Job Performance } \\
A V E=0.664 \\
C R=0.887\end{array}$} & Work Well-being & Meaningfulness in work-life & WWB1 & 0.76 & 19.11 \\
\hline & $\mathrm{AVE}=0.611$ & Good social relation & WWB2 & 0.65 & 15.48 \\
\hline & $\mathrm{CR}=0.819$ & Engagement in work & WWB3 & 0.51 & 11.3 \\
\hline & & Self-actualization & WWB4 & 0.54 & 12.13 \\
\hline & & Independence & WWB5 & 0.57 & 9.72 \\
\hline & & Pleasant state & WWB6 & 0.86 & 22.06 \\
\hline & & Self-acceptance & WWB7 & 0.72 & 18.08 \\
\hline & Task Performance & Task completion & TP1 & 0.71 & 13.21 \\
\hline & $\mathrm{AVE}=0735$ & Have work priority & TP2 & 0.8 & 15.55 \\
\hline & $\mathrm{CR}=0.892$ & Overcome limitations & TP3 & 0.72 & 14.3 \\
\hline & Contextual Performance & & & & \\
\hline & & Altruist behavior & $\mathrm{CP} 1$ & 0.83 & 15.17 \\
\hline & & Sportive attitude & $\mathrm{CP} 2$ & 0.73 & 16.45 \\
\hline & $\mathrm{AVE}=0.765$ & Civic virtue & $\mathrm{CP} 3$ & 0.75 & 17.01 \\
\hline & $\mathrm{CR}=0.929$ & Courtesy & $\mathrm{CP} 4$ & 0.8 & 17.56 \\
\hline & Adaptive Performance & & & & \\
\hline & $\mathrm{AVE}=0.811$ & Learn new things & AP1 & 0.86 & 14.79 \\
\hline & $\mathrm{CR}=0.876$ & Fast to adapt & AP2 & 0.77 & 16.85 \\
\hline & & Aware of new opportunities & IP1 & 0.71 & 16.01 \\
\hline & Innovative Performance & Generate new ideas & IP2 & 0.79 & 15.66 \\
\hline & $\mathrm{AVE}=0.689$ & Promote new ideas & IP3 & 0.78 & 15.59 \\
\hline & $\mathrm{CR}=0.899$ & Implementation of new ideas & IP4 & 0.75 & 15.38 \\
\hline
\end{tabular}


As Table 1 indicates, all indicators had loading factor value higher than the threshold value of 0.5 with t-value of 1.96 , indicating that all of the indicators had been valid in measuring each of the latent variables. Next, based on the value of AVE and $\mathrm{CR}$, both in the $1 \mathrm{st}$ and 2 nd order, all of the dimensions and the latent variables had exceeded their respective threshold $(A V E>0.5$ and $C R>0.7)$, indicating that the dimensions and variables are reliable. Indicators and dimensions in this study are reflective (Sekaran \& Bougie, 2016). The next stage was the analysis of the structural model to determine whether the hypothesis stating that work well-being affects job performance is acceptable. The first stage was examining the structural model fit the empirical data as shown by the indicators of Goodness of Fit (GoF). From the values of RMSEA=0.067, NFI $=0.99$, $\mathrm{NNFI}=0.98, \mathrm{CFI}=0.99, \mathrm{SRMR}=0.042$, it can be concluded that the model fit the empirical data. Thus, hypothesis testing could be done. The testing was done by comparing the t-value measurement result with the critical t-value (alpha $=1.96$ to 0:05 two-tailed). The result obtained t-value of 12.63 ( $\beta=0.80)$; thus, the null-hypothesis stating that work well-being had no influence on job performance was rejected and the research hypothesis (H1) that work well-being affects job performance was accepted. The determination coefficient (R2) value is 0.64 , which means there is $64 \%$ variance of Job Performance which can be determined by Work Well-being, while the rest is determined by other factors. This is shown in Figure 1 below.

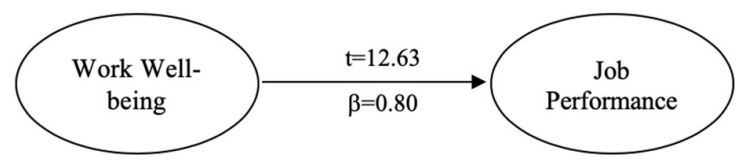

Figure 1. Structural Model

These results are in line with those of earlier studies by Bouckenooghe et al. (2013), Jiang and Tagard (2014), and Oswald et al. (2015). Employees who had positive emotions and were satisfied with their jobs had broader attention and mental flexibility that were critical to the completion of their tasks and responsibilities. Even well beyond that, they also felt that they had meaningful life, were able to contribute to their environment, and were respected by their colleagues. This sometimes motivates them to go the extra-mile to support their company's goal, even in unprecedented and creative ways. Happy employees are more productive than average (Oswald et al., 2015) and often generate novel ideas for the achievement of the organization's goals (Jiang \& Tagard, 2014). This phenomenon can be explained by the broaden-and-build theory of positive emotion (Fredrickson, 2009). Positive emotions will build thought-action repertoires, which later will build personal resources, either physical, intellectual, social, or psychological. Positivity will rouse open mind-set and curiosity, which will induce individuals to explore their environment, be open to new possibilities, and enjoy new challenges in a more creative way. Failures, thus, will be taken as part of learning, whereby individuals will be able to adapt to environmental changes and eventually attain better performance. De Neve and Oswald (2012) as well as Dijkhuizen et al. (2017) then concluded that well-being could predict individual performance in the future. Next, the effect of Work Well-being on Job Performance can also be explained by Weiss and Cropanzano's (1996) affective event theory. This theory explains that events in works can evoke affective reactions of individuals (often equated with emotion), which would then form work attitude. This becomes the basis of the establishment of performance. It also supports the theory that Work Well-being is seen as a process (means) to the behavior and not the goal (end) of the behavior.

Furthermore, transactional stress theory (Lazarus \& Folkman, 1984) describes how individuals respond to environmental stimuli (stressors). One of stress coping mechanisms that individuals use is meaning-based coping.

Although environmental challenges cause serious drain on resources, if the stimulus is considered to have a greater meaning, individuals may experience positive emotions and are motivated to perform well. This is shown by the indicator of meaningful work-life in measuring Work Well-being that contributes to the improvement of Job Performance. This study addresses the inconsistencies of previous studies (among others Tenney et al., 2016; Warr \& Nielson, 2018) related to the effect of wellbeing on performance.

\section{Conclusion and Suggestions}

This research has successfully proven the significant, positive effect of work well-being on job performance and answered the inconsistencies in previous studies. This will enable companies to improve their employees' performance through positive approaches by stressing the aspects that will improve work well-being. Work well-being improvement programs are ones that need organizational engineering, involve considerable resources, have an effect on the organization as a whole, and are longterm-oriented. Thus, the implementation of such programs requires commitment of the top management part in strategic decision-making. Interventions for improving employees' work well-being can be administered at three levels. Primary level is aimed at engineering a work situation with an effect on individual well-being, including job-redesign, work culture change, flexible working, and work-life balance policies. Secondary level is aimed at improving individuals' awareness, resilience, and capabilities in facing work stresses, for example, through better leadership and management practices. The interventions at this level may take the form of better recruitment and selection processes, development of management programs that are oriented to employees' well-being improvement, stress management training, and healthy-lifestyle-oriented activities. Lastly, tertiary level is aimed at helping employees who are facing problems, either at work or in other aspects of their life, through counselling or employee's assistance program. The results of this study also bring some implications as follows: First, social 
scientists and even economists need to provide further attention to work well-being as one of the forces that affect performance. Second, the results of this study are relevant to managers and human capital specialists because they provide consequences for the firm's promotion policies. Moreover, finally, because work well-being has been proven to increase job performance, the results of this study can also play a role at the microeconomic level even at the macroeconomic level, about how to produce self-sustaining spirals between human productivity and human well-being.

\section{References}

Albuquerque, A. S., \& Troccoli, B. T. (2004). Development a measure of subjective well-being. Psicologia, 20, $153-164$.

Amelia, A. (2018) Employer branding: When HR is the new marketing. Jakarta, Indonesia: Penerbit Buku Kompas.

Anderson, J. C., \& Gerbing, D. W. (1988). Structural equation modeling in practice: A review of recommended two step approach. Psychological Bulletin, 103(3), 411-423.

BCG (2012). Creating people advantage: Mastering HR challenges in a two speed world.

Bouckenooghe, D., Raja, U., \& Butt, A. N. (2013). Combined effect of positive and negative affectivity and job satisfaction on job performance and turnover intentions. Journal of Psychology: Interdisciplinary and Applied, 147(2), $105-123$.

Campbell, J. P. (1990) Modeling the performance prediction problem in industrial and organizational psychology. Dalam M. D. Dunnette and L. M. Hough (Eds.) Handbook of Industrial and Organizational Psychology. Palo Alto, CA: Consulting Psychologist Press, 687-732.

Campbell, J. P., \& Wiernik, B. M. (2015) The modeling and assessment of work performance. Annual Review of Organizational Psychology and Organizational behavior, 2, 47-74.

Colquitt, J. A., LePine, J. A., \& Wesson, M. J. (2017). Organizational behavior: Improving performance and commitment in the work place. $5^{\text {th }}$ ed. New York, NY: McGraw-Hill Education.

De Neve, J. E., \& Oswald, A. J. (2012). Estimating the influence of life satisfaction and positive affect on later income using sibling fixed effects. Proceedings of the National Academy of Sciences, 109(49), 19953-19958.

Deci, E. L., \& Ryan, R. M. (2008). Self-determination theory: A macro-theory of human motivation, development, and health. Canadian Psychology/Psychologie Canadienne, 49(3), 182-185.

DeVellis, R. F. (2016). Scale development: Theory and applications (Applied social research methods). California, CA: Sage Publications.

Diener, E., \& Chan, M. Y. (2011). Happy people live longer: Subjective well-being contributes to health and longevity. Applied Psychology: Health and Well-being, 3, 1-43.

Diener, E., Wirtz, D., Tov, W., Kim-Prieto, C., Choi, D. W., Oishi, S., \& Biswar-Diener, R. (2010) New well-being measures: Short scales to assess flourishing and positive and negative feelings. Social Indicators Research, 97(2), 143156.

Diener, E., Emmons, R. A., Larsen, R. J., \& Griffin, S. (1985). The satisfaction with life scale. Journal of Personality Assessment, 49, 71-75.

Dijkhuizen, J., Gorgievski, M., van Veldhoven, M., \& Schalk, R. (2017). Well-being, personal success and business performance among entrepreneurs: A two-wave study. Journal of Happiness Study, 5(4), 23-35.

Doll, W. J., Xia, W., \& Torkzadeh, G. (1994). A confirmatory factor analysis of the end-user computing satisfaction instrument. MIS Quarterly, 18(4), 453-461.

Ertugrul, M. (2013). Employee-friendly acquirers and acquisition performance. Journal of Financial Research, 36(3), $347-$ 370.

Fay, D., \& Sonnentag, S. (2010) A look back to move ahead: New directions for research on proactive performance and other discretionary work behaviors. Applied Psychology an International Review, 59, 1-20.

Fonseca, P. N., Nascimento, B. A., Barbosa, L., Vione, K. C., \& Gouveia, V. V. (2015). Flourishing scale: Evidence of its suitability to the Brazilian context. Social Inquiry into Well-being, 1(2), 33-40.

Fredrickson, B. L. (2009) Positivity. New York, NY: Crown

Giacomoni, C. H. (2004). Subjective well-being: looking for life quality. Temas em Psicologia, 12, 43-50.

Gratton, L. (2011) The shift: The future of work is already here. London, UK: HarperCollins Publisher.

Haneberg, L. (2011). Training for agility: Building the skills of employees need to zig and zag. Training and Development, September 2011, 51-56.

Huppert, F. A., \& So, T. T. (2013). Flourishing across Europe: Application of a new conceptual framework for defining well-being. Social Indicators Research, 110, 837-861.

Jiang, M., \& Tagard, P. (2014). Creative cognition and social innovation. Creativity Research Journal, $26(4), 375-388$.

Kagan, J. (2016). An overly permissive extension. Perspectives on Psychological Science, 11(4), 442-450.

Kaufman, J. C., \& Sternberg, R. J. (Eds.) (2010). The Cambridge handbook of creativity. New York, NY: Cambridge University Press.

Keyes, C. L., \& Simoes, E. J. (2012). To flourish or not: Positive mental health and all cause mortality. American Journal of Public Health, 102, 2164-2172.

Kim, Y., \& Ployhart, R. E. (2014) The effects of staffing and trainning on firm productivity and profit growth before, during, and after the great recession. Journal of Applied Psychology, 99(3), 361-389.

Koo, J., \& Suh, E. M. (2013). The influence of happiness on future income and job performance. Korean Journal of Social and Personality Psychology, 27, 17-36. 
Koopmans, L., Bernaards, C., Hildebrandt, V., van Buuren, S., van der Beek, A. J., \& de Vet, H. C. W. (2013) Development of an individual work performance questionnaire. International Journal of Productivity and Performance Management, 62(1), 6-28.

Manpower Group (2014). The talent shortage continuous: How the ever changing role of HR can bridge the gap. Dowloaded from http://www.manpowergroup.us/campaigns/talent-shortage-2014/assets/pdf/2014_Talent_Shortage WP_US.pdf

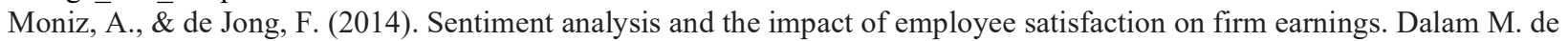 Rijke, T. Kenter, A. De Vries, C. Zhai, F. de Jong, K. Radinsky, and K. Hofmann (Eds.), Advances in Information Retrieval (pp. 519-527). London, UK: Springer-Verlag.

Motowidlo, S. J., Borman, W. C., \& Schmit, M. J. (1997). A theory of individual differences in task and contextual performance. Human Performance, 10(2), 71-83.

Murphy, K. R. (1989). Dimensions of job performance. Dalam R. F Dillon and J. W. Pellegrino (Eds.) Testing: Theoretical and Applied Perspectives. New York, NY: Praeger, 218-247.

Murphy, S. C., von Hippel, W., Dubbs, S. L., Angilletta, M. J., Wilson, R. S., and Trivers, R., et al. (2015). The role of overconfidence in romantic desirability and competition. Personality and Social Psychology Bulletin, 41(8), $1036-1052$.

Oswald, A. J., Proto, E., \& Sgroi, D. (2015). Happiness and productivity. Journal of Labor Economics, 33(4), 789-822.

Podsakoff, P. M., MacKenzie, S. B., Lee, J. Y., \& Podsakoff, N. P. (2003). Common method biases in behavioral research: A critical review of the literature and recommended remedies. Journal of Applied Psychology, 88(5), 879-903.

Reijonen, H., \& Komppula, R. (2007). Perception of success and its effect on small firm performance. Journal of Small Business and Enterprise Development, 14, 689-701.

Ryff, C. D., \& Keyes, C. L. M. (1995) The structure of psychological well-being revisited, Journal of Personality and Social Psychology, 69(4), 719-727.

Ryff, C. D. (2013). Psychological well-being revisited: Advances in the science and practice of eudaimonia. Psychotherapy and Psychosomatics, 83(1), 10-28.

Schotanus-Dijkstra, M., Pieterse, M. E., Drossaert, C., Westerhof, G. J. et al. (2016). What factors are associated with flourishing? Results from a large representative national sample. Journal of Happiness Studies, 17(4), 1351-1370.

Seligman (2011). Flourish: A visionary new understanding of happiness and well-being. New York, NY: Atria.

Shipton, H., Budhwar, P., Sparrow, P., \& Brown, A. (2016) Human resource management, innovation and performance. New York, NY: Palgrave Macmillan.

Silva, A. J., \& Caetano, A. (2013). Validation of the flourishing scale and scale of positive and negative experience in Portugal. Social Indicators Research, 110, 469-478.

Sinclair, R. R., \& Tucker, J. S. (2006) Stress-care: An integrated model of individual differences in soldier performance under stress. Dalam T. W. Britt, C. A. Castro, and A. B. Adler (Eds.) Military Life: The Psychology of Serving in Peace and Combat, Vol. 1, Militery Performance, Westport, CT: Praeger Security International, 202-231.

Spanuth, T., \& Wald, A. (2017) How to unleash the innovative work behavior of project staff? The role of affective and performance-based factors. International Journal of Project Management, 35, 1302-1311.

Sumi, K. (2013). Reliability and validity of Japanese versions of flourishing scale and the scale of positive and negative experience. Social Indicators Research, 1, 1-15.

Tenney, E. R., Poole, J. M., \& Diener, E. (2016). Does positivity enhance work performance? Why, when, and what we don't know. Research in Organizational Behavior, 36, 27-46.

Wach, D., Stephan, U., \& Gorgievski, M. J. (2016). More than money: Developing an integrative multifactorial measure of entrepreneurial success. International Small Business Journal, 34, 1098-1121.

Warr, P., \& Nielsen, K. (2018) Well-being and work performance. Dalam E. Diener, S. Oishi, and L. Tay (Eds.), Handbook of Well-being. Salt Lake City, UT: DEF Publishers.

Waterman, A. S., Schwartz, S. J., Zamboanga, B. L., et al. (2010). The questionnaire for eudaimonic well-being: Psychometric properties, demographic comparisons, and evidence of validity. The Journal of Positive Psychology, 5, 41-61.

Watson, D., Clark, L. A., \& Tellegen, A. (1988). Development and validation of brief measures of positive and negative affect: The PANAS scales. Journal of Personality and Social Psychology, 54, 1063-1070.

Wijanto, S. H. (2015). Metode Penelitian: Menggunakan structural equation modeling dengan Lisrel 9. Jakarta, Indonesia: Lembaga Penerbit Fakultas Ekonomi Universitas Indonesia.

Woyciekoski, C., Stenert, F., \& Hutz, C. S. (2012). Determinants of the subjective well-being. Psico, 43, 220-288.

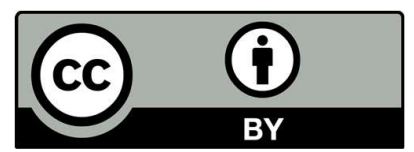

(C) 2020 by the authors; licensee Growing Science, Canada. This is an open access article distributed under the terms and conditions of the Creative Commons Attribution (CC-BY) license (http://creativecommons.org/licenses/by/4.0/). 